\title{
Association of single nucleotide polymorphisms in candidate genes previously related to genetic variation in fertility with phenotypic measurements of reproductive function in Holstein cows
}

\author{
M. Sofia Ortega, ${ }^{\star}$ Anna C. Denicol, ${ }^{* 1}$ John B. Cole, $†$ Daniel J. Null, $†$ Jeremy F. Taylor, $\ddagger$ Robert D. Schnabel, $¥ \S$ \\ and Peter J. Hansen*2 \\ *Department of Animal Sciences, D.H. Barron Reproductive and Perinatal Biology Research Program and Genetics Institute, University of Florida, \\ Gainesville 32611 \\ †Animal Genomics and Improvement Laboratory, Agricultural Research Service, USDA, Beltsville, MD 20705 \\ ‡Division of Animal Sciences, and \\ §Informatics Institute, University of Missouri, Columbia 65211
}

\section{ABSTRACT}

Many genetic markers related to health or production traits are not evaluated in populations independent of the discovery population or related to phenotype. Here we evaluated 68 single nucleotide polymorphisms (SNP) in candidate genes previously associated with genetic merit for fertility and production traits for association with phenotypic measurements of fertility in a population of Holstein cows that was selected based on predicted transmitting ability (PTA) for daughter pregnancy rate (DPR; high, $\geq 1, \mathrm{n}=989$; low, $\leq-1.0$, $\mathrm{n}=1,285$ ). Cows with a high PTA for DPR had higher pregnancy rate at first service, fewer services per conception, and fewer days open than cows with a low PTA for DPR. Of the 68 SNP, 11 were associated with pregnancy rate at first service, 16 with services per conception, and 19 with days open. Single nucleotide polymorphisms in 12 genes (BDH2, BSP3, CAST, CD2, CD14, FUT1, FYB, GCNT3, HSD17B7, IBSP, OCLN, and $P C C B$ ) had significant associations with 2 fertility traits, and SNP in 4 genes (CSPP1, FCER1G, PMM2, and TBC1D24) had significant associations with each of the 3 traits. Results from this experiment were compared with results from 2 earlier studies in which the SNP were associated with genetic estimates of fertility. One study involved the same animals as used here, and the other study was of an independent population of bulls. A total of 13 SNP associated with 1 or more phenotypic estimates of fertility were directionally associated with genetic estimates of fertility in the same

Received November 6, 2016

Accepted January 7, 2017.

${ }^{1}$ Present address: Department of Animal Sciences, University of California, Davis, CA 95616.

${ }^{2}$ Corresponding author: pjhansen@ufl.edu cow population. Moreover, 14 SNP associated with reproductive phenotype were directionally associated with genetic estimates of fertility in the bull population. Nine SNP (located in BCAS, BSP3, CAST, FUT1, HSD17B7, OCLN, PCCB, PMM2, and TBC1D24) had a directional association with fertility in all 3 studies. Examination of the function of the genes with SNP associated with reproduction in more than one study indicates the importance of steroid hormones and immune function as determinants of reproductive function. All but 1 of the 68 evaluated SNP were variable in 11 breeds besides Holstein, indicating the potential effects of these SNP on reproductive function across breeds of cattle.

Key words: reproduction, candidate genes, Holstein

\section{INTRODUCTION}

The use of genomics has improved response to selection for functional traits with low heritability such as daughter pregnancy rate (DPR) and productive life (García-Ruiz et al., 2016). Much of the work on fertility traits has been performed through use of genome-wide association studies (GWAS) to identify genetic loci associated with reproductive traits (Cole et al., 2011; Minozzi et al., 2013; Nayeri et al., 2016). One outcome has been the identification of haplotypes affecting fertility in dairy breeds (VanRaden et al., 2011; Larkin et al., 2012; Sahana et al., 2013; Cooper et al., 2014; Cuyabano et al., 2014) and identification of loss-of-function mutations that are embryo lethal (Fritz et al., 2013; Sonstegard et al., 2013).

The basis for GWAS is the assumption that the SNP on the panel are in linkage disequilibrium with causative mutations. In many cases, identification of the causative mutation is difficult because an associated genetic marker can often be located in an intergenic region and can be in linkage disequilibrium with vari- 
ants in several nearby genes. Another approach is to identify the causative SNP in the regulatory or coding region of a gene that is responsible for genetic variation in biological function. The causative allelic variant is expected to be more strongly associated with a trait than other SNP in linkage disequilibrium. Moreover, the allelic association between a functional mutation and a genetically controlled trait would be more likely to extend across breeds than a genetic marker based on linkage disequilibrium (Zhu and Zhao, 2007; Weller and Ron, 2011). Understanding the biological basis of genetic variation could also lead to insights into the underlying physiology controlling a trait. One approach to identify causative mutations is the candidate gene approach. Among the genes with SNP associated with reproductive traits in cattle are DGAT1, CAST, GHR, and $L E P R$ for services per conception and DPR (Garcia et al., 2006; Schneider et al., 2013; Hill et al., 2016); $I G F 1$ for resumption of ovarian cyclicity (Nicolini et al., 2013); and HSPA1L, STAT1, STAT3, PARM1, and $W B P 1$ for fertilization and embryonic development during the preimplantation period (Khatib et al., 2009; Cochran et al., 2013b).

For many genetic markers, SNP have not been independently evaluated in separate populations. When they are, replication of the effects is often poor (Ioannidis et al., 2001; Siontis et al., 2010; Littlejohn et al., 2012). Confidence in the relationship between a genetic mutation and phenotype is increased by replication of the allelic relationship in separate populations and by demonstrating that phenotype is also associated with the mutation. Here we evaluated the effect of $68 \mathrm{SNP}$ in candidate genes previously associated with genetic merit for fertility and production traits in Holstein cattle (Cochran et al., 2013a; Ortega et al., 2016) on phenotypic measurements of fertility and production in a population of Holstein cows. A fraction of the SNP was similarly associated with fertility traits in both studies (Cochran et al., 2013a; Ortega et al., 2016). The majority of the 68 SNP (64 of 68) are located in coding regions of genes and result in a change in the amino acid sequence of the encoded protein. We also evaluated whether the SNP were variable only in Holsteins or were common among multiple cattle breeds.

\section{MATERIALS AND METHODS}

\section{Phenotypic Measurements for Fertility and Milk Production}

Collection of Phenotypic Data from Genotyped Animals. Details of the animals included in the study and methods for genotyping were detailed in Ortega et al. (2016). Briefly, Holstein cows with a high $(\geq 1.5)$ or low $(\leq-1.0)$ PTA for DPR and located on 6 dairies in Florida and 5 in California were used. The high DPR group had 989 cows, and the low DPR group had 1285. Phenotypic data were collected for up to 5 lactations from each farm and combined with records from the national genetic evaluation system. Data for pregnancy rate at first service, services per conception, and days open (i.e., interval from calving to conception) were evaluated. Cows were genotyped for each of 68 SNP using a Sequenom MassARRAY system (iPLEX GOLD; Sequenom, San Diego, CA). The SNP were also previously described by Ortega et al. (2016). Of the 68 SNP, 48 were associated with 1 or more fertility traits [DPR, cow conception rate $(\mathbf{C C R})$ or heifer conception rate (HCR)] by Cochran et al. (2013a), and the remaining SNP were associated with milk production traits by Cochran et al. (2013a).

Data Analysis. The association of each genetic variant with phenotypic traits was performed by ANOVA using the Statistical Analysis System v 9.4 (SAS Institute Inc., Cary, NC). Days open and pregnancy rate were analyzed with the MIXED procedure. Days open were log-transformed before analysis to establish normality. The number of services per conception was analyzed with the GLIMMIX procedure using a negative binomial distribution for the responses and a logarithmic link function (Dobson, 2001).

In all analyses, genotype was considered a categorical variable. The full model was as follows:

$$
Y_{i j k l}=\mu+a_{i}+g_{j}+l_{k}+f_{l}+e_{i j k l},
$$

where $Y_{i j k l}$ is the value of the trait of interest for the $i$ th cow $(i=1,2, \ldots, \mathrm{n}), a_{i}$ is the random polygenic effect (including all available pedigree information) for the $i$ th cow, $g_{j}$ is the fixed effect of SNP genotype $(j=1, \ldots, 3$ such that $g_{1}$ is the genotypic value of $A A$ homozygotes, $g_{2}$ is the genotypic value of $A B$ heterozygotes, and $g_{3}$ is the genotypic value of $B B$ homozygotes), $l_{k}$ is the fixed effect of lactation number $(k=1, \ldots, 5), \mathrm{f}_{l}$ is the fixed effect of farm $(l=1, \ldots, 6)$, and $e_{i j k l}$ is the random residual effect. We assume that random polygenic effects $a \sim N\left(0, \mathbf{A} \sigma_{a}^{2}\right)$ and residuals $e \sim N\left(0, \sigma_{e}^{2}\right)$, where $\mathbf{A}$ is the numerator relationship matrix, $\sigma_{a}{ }^{2}$ is the additive genetic variance of the trait of interest, and $\sigma_{e}{ }^{2}$ is the residual error variance. All of the available pedigree information for each cow was used to generate $\mathbf{A}$, which models the covariance among the polygenic effects. Following Falconer and MacKay (1996), we estimated the a and d parameters for each locus as $\left(g_{3}-g_{1}\right) / 2$, and $g_{2}-\left(g_{1}+g_{2}\right) / 2$, respectively. Effects of $P<0.05$ were considered significant. 
Table 1. Phenotypes for fertility and production for animals classified based on predicted transmitting ability for daughter pregnancy rate $(\mathrm{DPR})$

\begin{tabular}{|c|c|c|c|c|c|c|c|}
\hline \multirow[b]{2}{*}{ Trait } & \multirow[b]{2}{*}{ Lactation } & \multicolumn{3}{|c|}{ Records, no. } & \multicolumn{2}{|c|}{ Least squares means (SEM) } & \multirow[b]{2}{*}{$P$-value } \\
\hline & & Total & High DPR & Low DPR & High DPR & Low DPR & \\
\hline \multirow{3}{*}{ first service, $\%$} & 3 & 1,743 & 821 & 922 & $41.0(1.88)$ & $25.0(2.53)$ & $<0.0001$ \\
\hline & 4 & 1,067 & 589 & 478 & $38.8(2.11)$ & $25.0(2.40)$ & $<0.0001$ \\
\hline & 5 & 484 & 305 & 179 & $38.3(2.94)$ & $15.1(4.00)$ & $<0.0001$ \\
\hline \multirow{3}{*}{ conception, no. } & 3 & 1,743 & 821 & 922 & $2.20(0.08)$ & $3.20(0.10)$ & $<0.0001$ \\
\hline & 4 & 1,067 & 589 & 478 & $2.34(0.12)$ & $3.22(0.28)$ & 0.0125 \\
\hline & 5 & 484 & 305 & 179 & $2.56(0.12)$ & $3.55(0.20)$ & 0.0960 \\
\hline \multirow{4}{*}{ Days open, d } & 1 & 2,274 & 989 & 1,285 & $98(2.59)$ & $163(2.94)$ & $<0.0001$ \\
\hline & 2 & 2,118 & 928 & 1,190 & $112(2.80)$ & $167(3.13)$ & $<0.0001$ \\
\hline & 3 & 1,743 & 821 & 922 & $110(3.24)$ & $158(3.81)$ & $<0.0001$ \\
\hline & 4 & 1,067 & 589 & 478 & $123(3.43)$ & $170(3.90)$ & $<0.0001$ \\
\hline
\end{tabular}

\section{Concordance of SNP Effects Across Studies}

Results on significant SNP effects associated with phenotype from the current study were compared with results from 2 other studies examining the effects of these 68 markers on estimates of genetic merit for reproductive and production traits. One study involved an independent population of 550 Holstein bulls (Cochran et al., 2013a), and the other evaluated genetic merit from the same cow population as in the present experiment (Ortega et al., 2016).

\section{Marker Frequencies in Other Breeds}

The variability of the 68 SNP evaluated in the present study was determined in other cattle breeds. The frequency of the genetic variants was determined in a total of 203 sequenced animals from 11 Bos taurus breeds: 109 Angus, 10 Beefmaster, 12 Charolais, 8 Gelbvieh, 18 Hereford, 3 Jersey, 9 Limousin, 5 Maine-Anjou, 14 Red Angus, 4 Romagnola, and 11 Simmental.

\section{RESULTS AND DISCUSSION}

\section{Effect of PTA for DPR on Phenotypic Measurements of Reproductive Function}

Pregnancy rate at first service, services per conception, and days open were all affected by DPR $(P<$ 0.0001, Table 1). In particular, cows with a high PTA for DPR had a higher pregnancy rate at first service, fewer services per conception, and fewer days open than cows with a low PTA for DPR. Note that the effect of DPR class was observed on pregnancy rate at first service, services per conception, and days open for each of the 5 examined lactations. These results confirm the usefulness of selection for DPR for improving reproductive function despite the low heritability associated with reproductive traits (VanRaden et al., 2004; Cochran et al., 2013a). Similar results have been obtained for a pasture-based production system (Cummins et al., 2012a).

The proportion of animals at later lactations was higher for the high DPR group than for the low DPR group. For example, the proportion of records represented from cows in fifth lactation was 305/3,603 (8.5\%) for the high DPR group versus $179 / 4,054$ (4.4\%) for the low DPR group. This result probably reflects culling for reproductive reasons, which has been estimated to represent 13 to $20 \%$ of all culling decisions (Hadley et al., 2006). Indeed, the genetic correlation between productive life and DPR is positive (Cochran et al., 2013a; VanRaden et al., 2014).

\section{SNP Associated with Fertility Traits}

Twenty-six SNP were associated with one or more phenotypic measures of fertility, with 11 SNP being associated with pregnancy rate at first service (Table 2), 16 being associated with services per conception (Table 3), and 19 being associated with days open (Table 4). Most SNP effects indicated a difference between homozygotes $(\mathrm{a}>0)$ or else both a and d effects were significant. Genes for which heterozygote deviations were found were FSHR, IBSP, and SERPINE2 for pregnancy rate at first service; $F Y B$ for services per conception; and $F Y B$ and IBSP for days open.

For 12 SNP, the same allele was positively and significantly associated with 2 fertility traits (BDH2, BSP3, CAST, CD14, CD2, FUT1, FYB, GCNT3, HSD17B\%, 
Table 2. Single nucleotide polymorphisms associated with pregnancy rate at first service

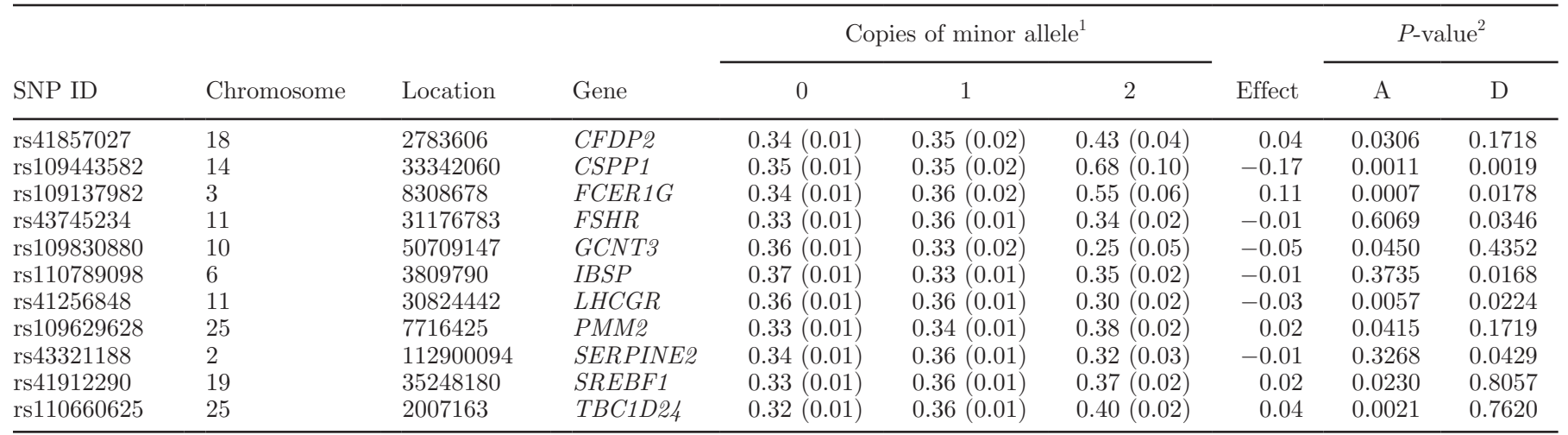

${ }^{1}$ Values are least squares means (SEM).

${ }^{2} \mathrm{~A}=$ one-half difference between homozygotes; $\mathrm{D}=$ deviation of heterozygotes from homozygote midpoint.

$I B S P$, $O C L N$, and $P C C B$ ), and 4 SNP had significant allelic associations with each of the 3 traits (CSPP1, FCER1G, PMM2, and TBC1D24).

\section{SNP with Effects Concordant in More than One Study}

Results from the current experiment were compared with results from earlier studies by Cochran et al. (2013a) and Ortega et al. (2016) to identify genes containing SNP in which (1) a significant association between the SNP and 1 or more reproductive traits was observed in at least 2 studies and (2) the allele associated with superior reproduction was the same in each case. Results are shown in Table 5, and 26 SNP met these criteria. A total of $13 \mathrm{SNP}$ associated with phenotypic measurements of fertility were also found to be directionally associated in genetic estimates of fertility using the same study population (Ortega et al., 2016). Moreover, 14 SNP associated with genetic estimates of fertility in the cow population (Ortega et al., 2016) were directionally associated with genetic estimates of fertility in an independent population of bulls (Cochran et al., 2013a). Nine SNP (located in BCAS, BSP3, CAST, FUT1, HSD17B7, OCLN, PCCB, $P M M 2$, and $T B C 1 D 24)$ had a directional association with fertility in all 3 studies.

The agreement of SNP effects between 2 independent populations compares favorably with other SNP associated with reproduction in which the degree of replication of SNP effects from one population to another ranged from 18\% (Höglund et al., 2014) to 0\% (Pryce et al., 2010). In a recent study, 93 of 245 QTL regions identified by GWAS as being related to cow fertility

Table 3. Single nucleotide polymorphisms associated with services per conception

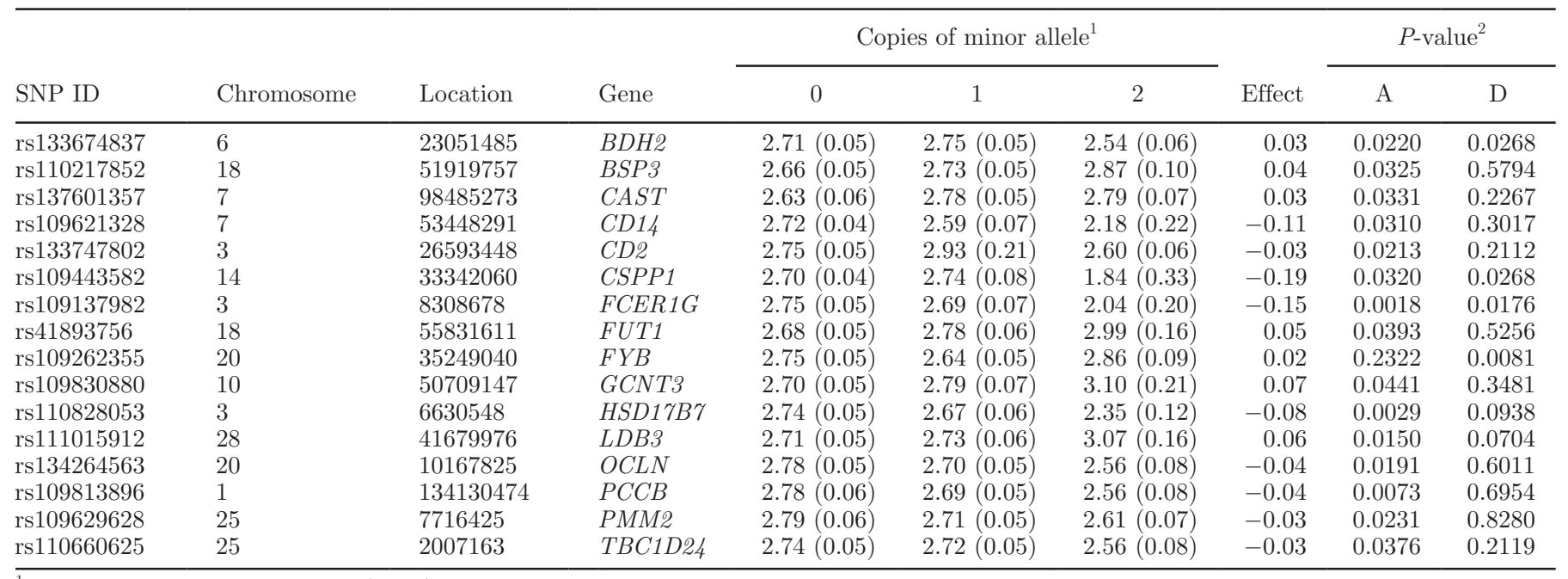

${ }^{1}$ Values are least squares means (SEM).

${ }^{2} \mathrm{~A}=$ one-half difference between homozygotes; $\mathrm{D}=$ deviation of heterozygotes from homozygote midpoint. 
Table 4. Single nucleotide polymorphisms associated with days open

\begin{tabular}{|c|c|c|c|c|c|c|c|c|c|}
\hline SNP ID & Chromosome & Location & Gene & \multicolumn{3}{|c|}{ Copies of minor allele $^{1}$} & Effect & \multicolumn{2}{|c|}{$P$-value ${ }^{2}$} \\
\hline rs109669573 & 13 & 82164839 & $B C A S 1$ & $141.5(2.3)$ & $142.7(2.2)$ & $147.7(3.2)$ & 3.08 & 0.0478 & 0.4033 \\
\hline rs110217852 & 18 & 51919757 & $B S P 3$ & $141.4(2.1)$ & $144.5(2.3)$ & $150.2(4.0)$ & 4.38 & 0.0481 & 0.7073 \\
\hline rs137601357 & 7 & 98485273 & $C A S T$ & $141.0(2.6)$ & $145.7(2.4)$ & $150.2(3.2)$ & 4.62 & 0.0066 & 0.8920 \\
\hline rs109621328 & 7 & 53448291 & $C D 14$ & $144.7(2.1)$ & $158.3(9.5)$ & $139.1(3.0)$ & -2.80 & 0.0089 & 0.0769 \\
\hline rs109137982 & 3 & 8308678 & $F C E R 1 G$ & $144.7(2.3)$ & $143.5(2.4)$ & $140.7(4.1)$ & -14.94 & 0.0018 & 0.0199 \\
\hline rs41893756 & 18 & 55831611 & FUT1 & $142.4(2.1)$ & $146.3(2.7)$ & $157.2(7.6)$ & -2.00 & 0.0474 & 0.2983 \\
\hline rs109262355 & 20 & 35249040 & $F Y B$ & $143.1(2.1)$ & $139.9(2.1)$ & $152.2(3.6)$ & 7.42 & 0.2029 & 0.0255 \\
\hline rs110828053 & 3 & 6630548 & $H S D 17 B 7$ & $144.2(2.1)$ & $144.3(2.7)$ & $130.8(6.4)$ & 4.54 & 0.0388 & 0.1411 \\
\hline rs110789098 & 6 & 3809790 & $I B S P$ & $141.2(2.5)$ & $147.8(2.3)$ & $140.5(3.6)$ & -6.73 & 0.8626 & 0.0180 \\
\hline rs109383758 & 18 & 62241722 & NLRP9 & $137.9(2.9)$ & $144.5(2.2)$ & $145.5(3.1)$ & -0.34 & 0.0428 & 0.3361 \\
\hline rs134264563 & 20 & 10167825 & $O C L N$ & $147.4(2.3)$ & $143.7(2.2)$ & $135.8(3.7)$ & 3.81 & 0.0108 & 0.4494 \\
\hline
\end{tabular}

${ }^{1}$ Values are least squares means (SEM).

${ }^{2} \mathrm{~A}=$ one-half difference between homozygotes; $\mathrm{D}=$ deviation of heterozygotes from homozygote midpoint.

Table 5. Single nucleotide polymorphisms associated with fertility traits in more than one study ${ }^{1}$

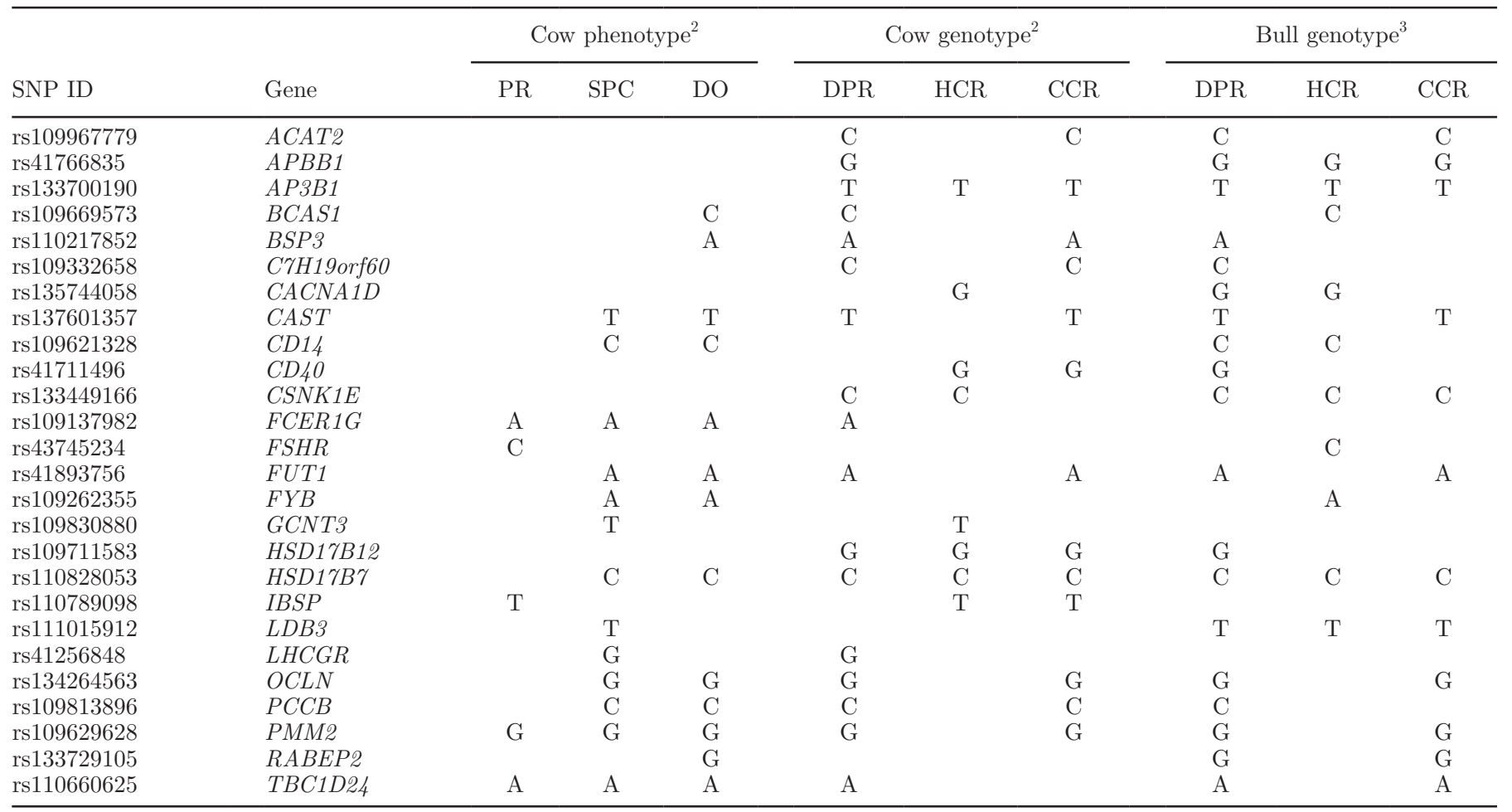

${ }^{1}$ Shown are genes containing SNP in which a significant association between the SNP and one or more reproductive traits was observed in at least 2 studies. The letter represents the allele associated with superior reproduction. SNP significant in more than one study but where different alleles were associated with superior reproduction are not included in the table. $\mathrm{CCR}=$ cow conception rate; DO $=$ days open; $\mathrm{DPR}=$ daughter pregnancy rate; $\mathrm{HCR}=$ heifer conception rate; $\mathrm{PR}=$ pregnancy rate; $\mathrm{SPC}=$ services per conception.

${ }^{2}$ Based on a population of 2,273 Holstein cows [Ortega et al. (2016) and present study].

${ }^{3}$ Based on a population of 550 Holstein bulls (Cochran et al., 2013a). 


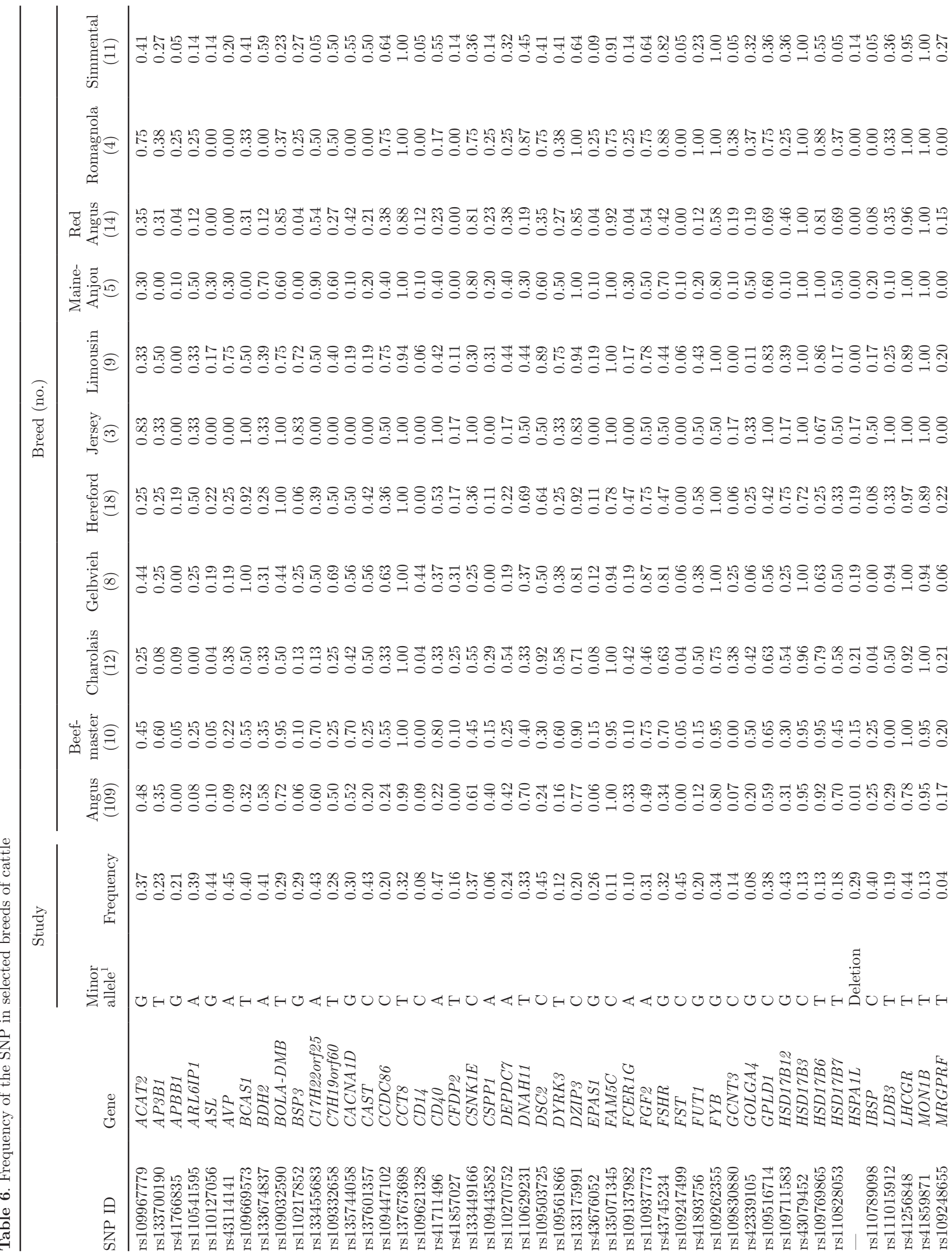




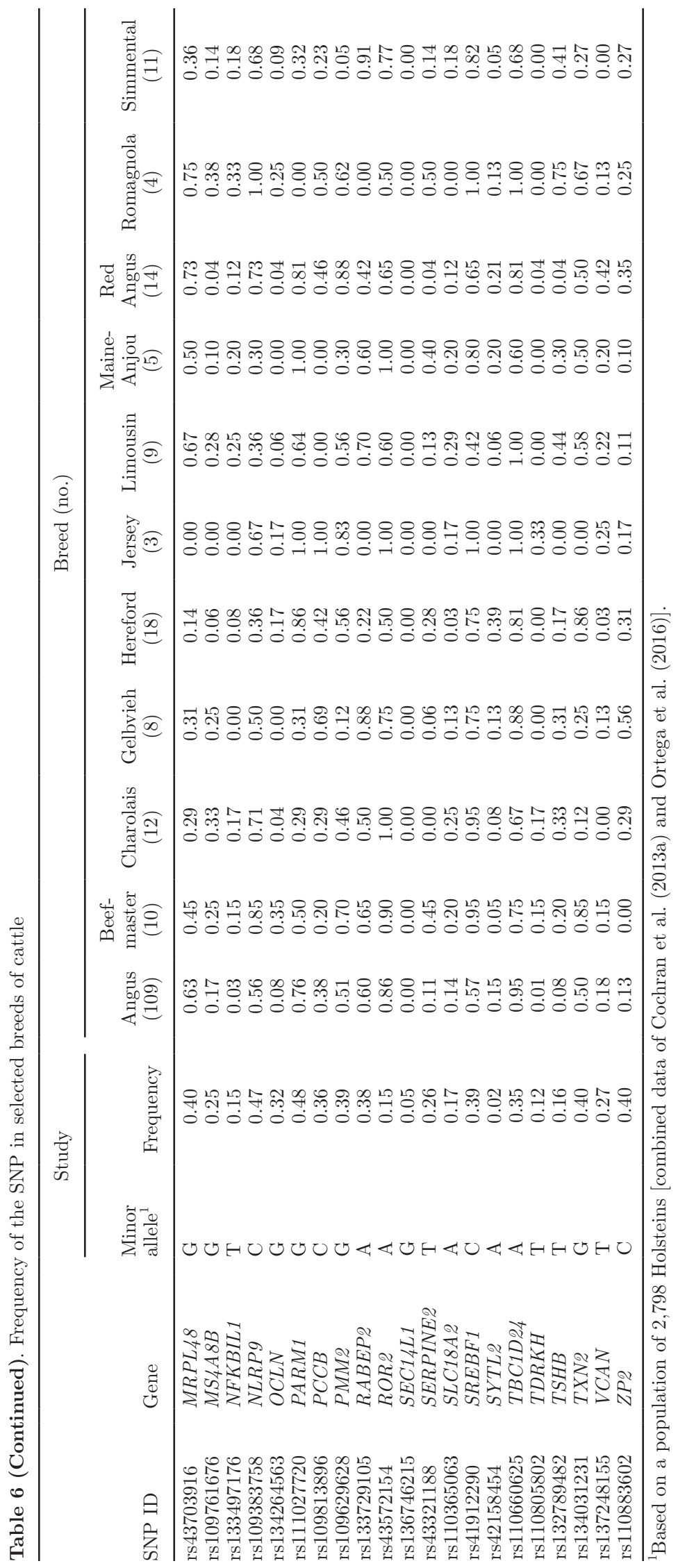


were repeatable in 2 independent GWAS (Moore et al., 2016). The consistency of the effect of SNP described in Table 5 across studies provides confidence that associations between many of the SNP and reproductive function reported by Cochran et al. (2013a) and Ortega et al. (2016) are real and not false positives. Moreover, a few of the genes found to be associated with reproductive traits across studies evaluated here have also been reported to be associated with reproductive traits in other reports. The SNP in CAST has been associated with genetic merit for DPR, days open, and productive life (Garcia et al., 2006; Hill et al., 2016). The SNP in $P C C B, P M M 2$, and TBC1D24 have previously been associated with percentage of cleaved embryos that develop to the blastocyst stage (Cochran et al., 2013b).

\section{Functional Ontology of SNP}

Examination of the function of genes that were repeatedly associated with reproductive traits (Table 5) provides an indication of physiological processes important for variation among cows in reproductive function. In earlier studies of these SNP (Cochran et al., 2013a; Ortega et al., 2016), pathway analysis of genes associated with fertility traits using Ingenuity Pathway Analysis indicated that 14 of these genes were regulated by estradiol and 6 were regulated by progesterone. Most of these steroid-regulated genes were among the list of 26 genes found to be associated with reproductive function in more than one study. The list included 9 estradiol-regulated genes (APBB1, BCAS1, CAST, HSD17B12, HSD17B7, LHCGR, OCLN, PMM2, and $R A B E P 2)$ and 4 progesterone-regulated genes (CD40, LHCGR, PMM2, and RABEP2). Besides steroid hormones being essential for reproduction in mammals, data indicate the importance of variation in their circulating concentrations for cow fertility. In beef cattle, preovulatory concentrations of estradiol are related to subsequent fertility (Perry et al., 2005; Jinks et al., 2013). For Holstein cows on pasture, those with high genetic merit for fertility had a larger corpus luteum and higher circulating concentrations of progesterone than cows with lower genetic merit (Cummins et al., 2012b; Moore et al., 2014). Progesterone concentrations on d 4 to 7 after AI were positively associated with pregnancy rate in Holstein heifers (Parr et al., 2012). Steroid hormones may be an especially important determinant of reproduction in lactating cows because of increased catabolism of steroids associated with lactation (Wiltbank et al., 2006, 2014).

The other function that was well represented in genes containing SNP identified earlier (Cochran et al., 2013a; Ortega et al., 2016) and in the present study was immune function. Of the 10 genes containing SNP related to reproductive traits that were involved in immune function as identified by Cochran et al. (2013a) or Ortega et al. (2016), 6 (CD14, CD40, FCER1G, FUT1, GCNT3, and RABEP2) were found to be related to fertility traits in more than one study (Table 5). Immune function is an important determinant of reproductive function, and dairy cows that experience one or more diseases postpartum have reduced reproductive function (Santos et al., 2010). Genes involved in inflammation are among those whose expression in endometrium, liver, and muscle differed between Holstein cows that were genetically divergent in fertility (Moran et al., 2015, 2016).

\section{Variability of the SNP in Other Breeds}

The variability of the 68 SNP studied here was evaluated in 11 B. taurus breeds (Table 6). All but one SNP was variable in each of the examined breeds. The exception was for $S E C 14 L 1$, which was variable only in Holstein. The variability of these SNP in other breeds indicates that they arose before the Holstein separated from other B. taurus breeds and that the SNP could be associated with reproductive function in breeds other than Holstein.

\section{CONCLUSIONS}

This study demonstrated that genetic differences in fertility are associated with differences in phenotype. This finding was true in comparisons of cows that diverged in predicted transmitting ability for DPR or in examination of the effects of specific SNP on reproductive function. A total of 26 SNP were identified for which the same allele was associated with increases in at least one reproductive trait in 2 separate studies. Examination of the function of genes represented by the $26 \mathrm{SNP}$ with concordant effects indicates the importance of steroid hormones and immune function as determinants of reproductive function. All but one of the studied SNP were variable in 11 breeds besides Holstein, indicating the potential association of these SNP with reproductive function in cattle in general.

\section{ACKNOWLEDGMENTS}

Research was supported by Agriculture and Food Research Initiative Competitive Grant no. 2013-6800420365 from the USDA National Institute of Food and Agriculture (Washington, DC), a grant from the Southeast Milk Inc. Milk Check-off Program, and funds from the L.E. "Red" Larson Endowment. Cole and Null were supported by appropriated project 1265-31000-096-00, "Improving Genetic Predictions in Dairy Animals Us- 
ing Phenotypic and Genomic Information," of the Agricultural Research Service of the USDA. The authors thank the dairies that formed part of the study: Davie 1 and 2 (Okeechobee, FL), University of Florida Dairy (Hague, FL), Genasci Brothers Dairy (Modesto, CA), Larson Dairy Barn 5 (Okeechobee, FL), Maddox and Ruann Dairies (Riverview, CA), North Florida Holsteins (Bell, FL), PH Dairies 1 and 2 Dairies (Winton, CA), and Shenandoah Dairy (Live Oak, FL). The authors also thank GeneSeek for outstanding cooperation in completion of the study. Thanks are also extended to the following for assistance with obtaining samples and data: Dr. Alvaro Magalhaes, Lander Veterinary Clinic (Turlock, CA), and Kelly Buchanan, Serdal Dikmen, Kyle Dobbs, Javier Juarez, James Moss, Antonio Ruiz de King, and Paula Tribulo from the University of Florida. The Council on Dairy Cattle Breeding (Reynoldsburg, $\mathrm{OH}$ ) and the Cooperative Dairy DNA Repository (Columbia, MO) are acknowledged for providing data used in this study. Mention of trade names or commercial products in this article is solely for the purpose of providing specific information and does not imply recommendation or endorsement by the USDA.

\section{REFERENCES}

Cochran, S. D., J. B. Cole, D. J. Null, and P. J. Hansen. 2013a. Discovery of single nucleotide polymorphisms in candidate genes associated with fertility and production traits in Holstein cattle. BMC Genet. 14:49 https://doi.org/10.1186/1471-2156-14-49.

Cochran, S. D., J. B. Cole, D. J. Null, and P. J. Hansen. 2013b. Single nucleotide polymorphisms in candidate genes associated with fertilizing ability of sperm and subsequent embryonic development in cattle. Biol. Reprod. 89:69 https://doi.org/10.1095/ biolreprod.113.111260.

Cole, J. B., G. R. Wiggans, L. Ma, T. S. Sonstegard, T. J. Lawlor, B. A. Crooker, C. P. Van Tassell, J. Yang, S. Wang, L. K. Matukumalli, and Y. Da. 2011. Genome-wide association analysis of thirty one production, health, reproduction and body conformation traits in contemporary U.S. Holstein cows. BMC Genomics 12:408.

Cooper, T. A., G. R. Wiggans, D. J. Null, J. L. Hutchison, and J. B. Cole. 2014. Genomic evaluation, breed identification, and discovery of a haplotype affecting fertility for Ayrshire dairy cattle. J. Dairy Sci. 97:3878-3882. https://doi.org/10.3168/jds.2013-7427.

Cummins, S. B., P. Lonergan, A. C. O. Evans, D. P. Berry, R. D. Evans, and S. T. Butler. 2012a. Genetic merit for fertility traits in Holstein cows: I. Production characteristics and reproductive efficiency in a pasture-based system. J. Dairy Sci. 95:1310-1322. https://doi.org/10.3168/jds.2011-4742.

Cummins, S. B., P. Lonergan, A. C. O. Evans, and S. T. Butler. 2012b. Genetic merit for fertility traits in Holstein cows: II. Ovarian follicular and corpus luteum dynamics, reproductive hormones, and estrus behavior. J. Dairy Sci. 95:3698-3710. https://doi. org/10.3168/jds.2011-4976.

Cuyabano, B. C., G. Su, and M. S. Lund. 2014. Genomic prediction of genetic merit using LD-based haplotypes in the Nordic Holstein population. BMC Genomics 15:1171 https://doi.org/10.1186/14712164-15-1171.

Dobson, A. J. 2001. An Introduction to Generalized Linear Models. 2nd ed. CRC Press, Boca Raton, FL.

Falconer, D. S., and T. F. C. MacKay. 1996. Introduction to Quantitative Genetics. 4th ed. Harlow, UK.
Fritz, S., A. Capitan, A. Djari, S. C. Rodriguez, A. Barbat, A. Baur, C. Grohs, B. Weiss, M. Boussaha, D. Esquerré, C. Klopp, D. Rocha, and D. Boichard. 2013. Detection of haplotypes associated with prenatal death in dairy cattle and identification of deleterious mutations in GART, SHBG and SLC37A2. PLoS One 8:e65550 https://doi.org/10.1371/journal.pone.0065550.

Garcia, M. D., J. J. Michal, C. T. Gaskins, J. J. Reeves, T. L. Ott, Y. Liu, and Z. Jiang. 2006. Significant association of the calpastatin gene with fertility and longevity in dairy cattle. Anim. Genet. 37:304-305. https://doi.org/10.1111/j.1365-2052.2006.01443.x.

García-Ruiz, A., J. B. Cole, P. M. VanRaden, G. R. Wiggans, F. J. Ruiz-López, and C. P. Van Tassell. 2016. Changes in genetic selection differentials and generation intervals in US Holstein dairy cattle as a result of genomic selection. Proc. Natl. Acad. Sci. USA 113:E3995-E4004. https://doi.org/10.1073/pnas.1519061113.

Hadley, G. L., C. A. Wolf, and S. B. Harsh. 2006. Dairy cattle culling patterns, explanations, and implications. J. Dairy Sci. 89:22862296. https://doi.org/10.3168/jds.S0022-0302(06)72300-1.

Hill, R., A. Canal, K. Bondioli, R. Morell, and M. D. Garcia. 2016. Molecular markers located on the DGAT1, CAST, and LEPR genes and their associations with milk production and fertility traits in Holstein cattle. Genet. Mol. Res. 15(1). https://doi.org/10.4238/ gmr.15017794.

Höglund, J. K., G. Sahana, B. Guldbrandtsen, and M. S. Lund. 2014. Validation of associations for female fertility traits in Nordic Holstein, Nordic Red and Jersey dairy cattle. BMC Genet. 15:8. https://doi.org/10.1186/1471-2156-15-8.

Ioannidis, J. P. A., E. E. Ntzani, T. A. Trikalinos, and D. G. Contopoulos-Ioannidis. 2001. Replication validity of genetic association studies. Nat. Genet. 29:306-309. https://doi.org/10.1038/ng749.

Jinks, E. M., M. F. Smith, J. A. Atkins, K. G. Pohler, G. A. Perry, M. D. MacNeil, A. J. Roberts, R. C. Waterman, L. J. Alexander, and T. W. Geary. 2013. Preovulatory estradiol and the establishment and maintenance of pregnancy in suckled beef cows. J. Anim. Sci. 91:1176-1185.

Khatib, H., C. Maltecca, R. L. Monson, V. Schutzkus, and J. J. Rutledge. 2009. Monoallelic maternal expression of STAT5A affects embryonic survival in cattle. BMC Genet. 10:13 https://doi. org/10.1186/1471-2156-10-13.

Larkin, D. M., H. D. Daetwyler, A. G. Hernandez, C. L. Wright, L. A. Hetrick, L. Boucek, S. L. Bachman, M. R. Band, T. V. Akraiko, M. Cohen-Zinder, J. Thimmapuram, I. M. Macleod, T. T. Harkins, J. E. McCague, M. E. Goddard, B. J. Hayes, and H. A. Lewin. 2012. Whole-genome resequencing of two elite sires for the detection of haplotypes under selection in dairy cattle. Proc. Natl. Acad. Sci. USA 109:7693-7698. https://doi.org/10.1073/pnas.1114546109.

Littlejohn, M., T. Grala, K. Sanders, C. Walker, G. Waghorn, K. Macdonald, R. Spelman, S. Davis, and R. Snell. 2012. Non-replication of genome-wide-based associations of efficient food conversion in dairy cows. Anim. Genet. 43:781-784. https://doi.org/10.1111/ j.1365-2052.2012.02327.x.

Minozzi, G., E. L. Nicolazzi, A. Stella, S. Biffani, R. Negrini, B. Lazzari, P. Ajmone-Marsan, and J. L. Williams. 2013. Genome wide analysis of fertility and production traits in Italian Holstein cattle. PLoS One 8:e80219 https://doi.org/10.1371/journal.pone.0080219.

Moore, S. G., J. E. Pryce, B. J. Hayes, A. J. Chamberlain, K. E. Kemper, D. P. Berry, M. McCabe, P. Cormican, P. Lonergan, T. Fair, and S. T. Butler. 2016. Differentially expressed genes in endometrium and corpus luteum of Holstein cows selected for high and low fertility are enriched for sequence variants associated with fertility. Biol. Reprod. 94:19 https://doi.org/10.1095/ biolreprod.115.132951.

Moore, S. G., S. Scully, J. A. Browne, T. Fair, and S. T. Butler. 2014. Genetic merit for fertility traits in Holstein cows: V. Factors affecting circulating progesterone concentrations. J. Dairy Sci. 97:5543-5557. https://doi.org/10.3168/jds.2014-8133.

Moran, B., S. T. Butler, S. G. Moore, D. E. MacHugh, and C. J. Creevey. 2015. Differential gene expression in the endometrium reveals cytoskeletal and immunological genes in lactating dairy cows genetically divergent for fertility traits. Reprod. Fertil. Dev. In press. 10.1071/RD15128. 
Moran, B., S. B. Cummins, C. J. Creevey, and S. T. Butler. 2016. Transcriptomics of liver and muscle in Holstein cows genetically divergent for fertility highlight differences in nutrient partitioning and inflammation processes. BMC Genomics 17:603 https://doi. org/10.1186/s12864-016-2938-1.

Nayeri, S., M. Sargolzaei, M. K. Abo-Ismail, N. May, S. P. Miller, F. Schenkel, S. S. Moore, and P. Stothard. 2016. Genome-wide association for milk production and female fertility traits in Canadian dairy Holstein cattle. BMC Genet. 17:75 https://doi.org/10.1186/ s12863-016-0386-1.

Nicolini, P., M. Carriquiry, and A. Meikle. 2013. A polymorphism in the insulin-like growth factor 1 gene is associated with postpartum resumption of ovarian cyclicity in Holstein-Friesian cows under grazing conditions. Acta Vet. Scand. 55:11 https://doi. org/10.1186/1751-0147-55-11.

Ortega, M. S., A. C. Denicol, J. B. Cole, D. J. Null, and P. J. Hansen. 2016. Use of single nucleotide polymorphisms in candidate genes associated with daughter pregnancy rate for prediction of genetic merit for reproduction in Holstein cows. Anim. Genet. 47:288-297. https://doi.org/10.1111/age.12420.

Parr, M. H., M. P. Mullen, M. A. Crowe, J. F. Roche, P. Lonergan, A. C. O. Evans, and M. G. Diskin. 2012. Relationship between pregnancy per artificial insemination and early luteal concentrations of progesterone and establishment of repeatability estimates for these traits in Holstein-Friesian heifers. J. Dairy Sci. 95:2390-2396. https://doi.org/10.3168/jds.2011-4498.

Perry, G. A., M. F. Smith, M. C. Lucy, J. A. Green, T. E. Parks, M. D. MacNeil, A. J. Roberts, and T. W. Geary. 2005. Relationship between follicle size at insemination and pregnancy success. Proc. Natl. Acad. Sci. USA 102:5268-5273. https://doi.org/10.1073/ pnas.0501700102.

Pryce, J. E., S. Bolormaa, A. J. Chamberlain, P. J. Bowman, K. Savin, M. E. Goddard, and B. J. Hayes. 2010. A validated genome-wide association study in 2 dairy cattle breeds for milk production and fertility traits using variable length haplotypes. J. Dairy Sci. 93:3331-3345. https://doi.org/10.3168/jds.2009-2893.

Sahana, G., U. S. Nielsen, G. P. Aamand, M. S. Lund, and B. Guldbrandtsen. 2013. Novel harmful recessive haplotypes identified for fertility traits in Nordic Holstein cattle. PLoS One 8:e82909 https://doi.org/10.1371/journal.pone.0082909.

Santos, J. E. P., R. S. Bisinotto, E. S. Ribeiro, F. S. Lima, L. F. Greco, C. R. Staples, and W. W. Thatcher. 2010. Applying nutrition and physiology to improve reproduction in dairy cattle. Soc. Reprod. Fertil. Suppl. 67:387-403.

Schneider, A., M. N. Corrêa, and W. R. Butler. 2013. Association between growth hormone receptor AluI polymorphism and fertility of Holstein cows. Theriogenology 80:1061-1066. https://doi. org/10.1016/j.theriogenology.2013.08.006.

Siontis, K. C. M., N. A. Patsopoulos, and J. P. A. Ioannidis. 2010 Replication of past candidate loci for common diseases and phenotypes in 100 genome-wide association studies. Eur. J. Hum. Genet. 18:832-837. https://doi.org/10.1038/ejhg.2010.26.

Sonstegard, T. S., J. B. Cole, P. M. VanRaden, C. P. V. Tassell, D. J. Null, S. G. Schroeder, D. Bickhart, and M. C. McClure. 2013. Identification of a nonsense mutation in $C W C 15$ associated with decreased reproductive efficiency in Jersey cattle. PLoS One 8:e54872 https://doi.org/10.1371/journal.pone.0054872.

VanRaden, P. M., K. M. Olson, D. J. Null, and J. L. Hutchison. 2011. Harmful recessive effects on fertility detected by absence of homozygous haplotypes. J. Dairy Sci. 94:6153-6161. https://doi. org/10.3168/jds.2011-4624.

VanRaden, P. M., A. H. Sanders, M. E. Tooker, R. H. Miller, H. D. Norman, M. T. Kuhn, and G. R. Wiggans. 2004. Development of a national genetic evaluation for cow fertility. J. Dairy Sci. 87:22852292. https://doi.org/10.3168/jds.S0022-0302(04)70049-1.

VanRaden, P. M., M. E. Tooker, J. R. Wright, C. Sun, and J. L. Hutchison. 2014. Comparison of single-trait to multi-trait national evaluations for yield, health, and fertility. J. Dairy Sci. 97:79527962. https://doi.org/10.3168/jds.2014-8489.

Weller, J. I., and M. Ron. 2011. Invited review: Quantitative trait nucleotide determination in the era of genomic selection. J. Dairy Sci. 94:1082-1090. https://doi.org/10.3168/jds.2010-3793.

Wiltbank, M., H. Lopez, R. Sartori, S. Sangsritavong, and A. Gümen. 2006. Changes in reproductive physiology of lactating dairy cows due to elevated steroid metabolism. Theriogenology 65:17-29. https://doi.org/10.1016/j.theriogenology.2005.10.003.

Wiltbank, M. C., A. H. Souza, P. D. Carvalho, A. P. Cunha, J. O. Giordano, P. M. Fricke, G. M. Baez, and M. G. Diskin. 2014 Physiological and practical effects of progesterone on reproduction in dairy cattle. Animal 8:70-81. https://doi.org/10.1017/ S1751731114000585.

Zhu, M., and S. Zhao. 2007. Candidate gene identification approach: Progress and challenges. Int. J. Biol. Sci. 3:420-427. 